\title{
PENERAPAN METODE INKUIRI BERBANTUAN MEDIA BENDA KONKRET DAPAT MENINGKATKAN HASIL BELAJAR MATEMATIKA
}

\author{
I Made Citra Wibawa ${ }^{1, *}$, I Ketut Tunas Arnawa ${ }^{2}$ \\ 1Jurusan Pendidikan Guru Sekolah Dasar. Universitas Pendidikan Ganesha, Indonesia \\ 2Jurusan Pendidikan Guru Sekolah Dasar. Universitas Pendidikan Ganesha, Indonesia
}

\begin{abstract}
Abstrak
Penelitian ini bertujuan untuk mengetahui peningkatan hasil belajar Matematika setelah diberikan tindakan berupa Penerapan Metode Inkuiri Berbantuan Media Benda Konkret dalam pembelajaran Matematika siswa kelas III Semester 2 dengan jumlah siswa 10 orang, dengan jumlah siswa laki-laki 4 orang dan siswa perempuan 6 orang di SDN 6 Tianyar Barat, Kecamatan Kubu, Kabupaten Karangasem, diantaranya terdapat 5 orang siswa yang mengalami hasil belajar dibawah standar yang ditetapkan. Data hasil belajar yang telah terkumpul dianalisis dengan metode statistik diskriptif kuantitatif. Hasil penelitian ini menunjukan bahwa dengan penggunaan Metode Inkuiri Berbantuan Media Benda Konkret pada siswa kelas III Semester 2 SDN 6 Tianyar Barat dapat meningkatkan hasil belajar siswa dari rata-rata kelas 50\% (kurang) sebelum tindakan, setelah tindakan pada siklus I rata-rata nilai kelas adalah $54,6 \%$ (cukup). Besar peningkatan sebelum tindakan dan setelah tindakan pada siklus I sebesar $15 \%$ sedangkan nilai rata-rata kelas pada siklus II adalah $73,8, \%$ (Baik). besar peningkatan dari siklus I dan siklus II sebesar 19,2\% ini menunjukkan ada peningkatan dari siklus I dan siklus II dari kategori cukup menjadi kategori baik.
\end{abstract}

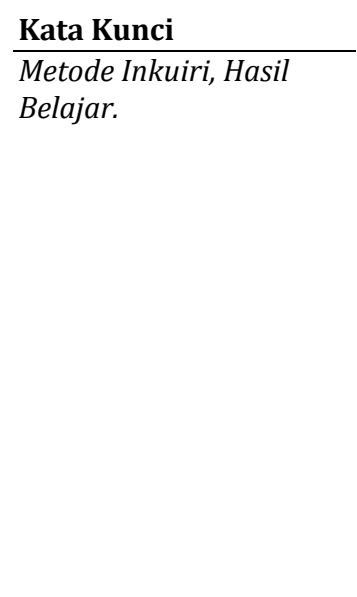

\section{Pendahuluan}

Kemajuan ilmu pengetahuan dan teknologi mengalami perkembangan yang sangat pesat. Oleh karena itu, dalam upaya mengantisipasi kemajuan ilmu pengetahuan dan teknologi tersebut sangat diperlukan sumber daya manusia yang sangat berkualitas, sebagai salah satu faktor penentu yang tidak boleh diabaikan. Hal ini sesuai dengan UU No.20 th 2003 yang menyatakan bahwa pendidikan nasional yang berfungsi mengembangkan kemampuan dan membentuk watak peradaban bangsa yang bermartabat dalam rangka mencerdaskan kehidupan bangsa, bertujuan untuk berkembangnya potensi siswa agar menjadi manusia yang beriman dan bertakwa kepada Tuhan Yang Maha Esa, berakhlak mulia, sehat, berilmu, cakap, kreatif, mandiri, dan menjadi warga negara yang demokratis serta bertanggung jawab. Untuk mencapai tujuan tersebut, maka pendidikan berlangsung seumur hidup dan dilaksanakan di lingkungan keluarga, sekolah, dan masyarakat.

Berdasarkan Undang-Undang No.20 Tahun 2003 tersebut, peran tenaga pendidik dalam hal ini guru sangat penting dalam mengembangkan potensi siswa. Potensi siswa dapat berkembang jika potensi yang dimiliki siswa tersebut terus digali dan ditumbuhkembangkan. Untuk itu, guru dituntut mampu menerapkan metode dan menggunakan media yang bisa mengaktifkan siswa. Selain itu guru juga diharapkan mampu memerankan dirinya sebagai motivator dan fasilitator dalam melaksanakan pembelajaran.

Dari hasil observasi, dalam pelaksanaan pembelajaran Matematika kelas III SD Negeri 6 Tianyar Barat realitanya guru belum sepenuhnya bisa mengaktifkan siswa. Di sisi lain guru juga mengalami masalah dalam melaksanakan proses pembelajaran. Berikut adalah beberapa masalah yang dihadapi guru di SD Negeri 6 Tianyar Barat pada kelas III yaitu: (a) siswa cepat bosan mendengarkan penjelasan guru, (b) siswa kelihatan mengerti dengan materi yang disampaikan guru, tetapi saat diberikan pertanyaan siswa mengalami kesulitan dalam menjawan pertanyaan guru, (c) siswa jarang bertanya dalam proses pembelajaran padahal sebenarnya mereka belum paham, dan (d) siswa kurang antusias dalam mengikuti 
pelajaran. Hal tersebut dikarenakan guru dalam mengajar mata pelajaran Matematika dengan topik pecahan masih menerapkan metode pembelajaran yang bersifat konvesional. Dalam menyampaikan materi pelajaran guru masih menerapkan metode ceramah dengan asumsi bahwa pengetahuan dapat langsung dipindahkan ke pemikiran siswa. Seharusnya guru menyadari cara pembelajaran seperti ini kurang tepat lagi untuk diterapkan.

Dari masalah-masalah yang dihadapi di SD Negeri 6 Tianyar Barat kelas III pada mata pelajaran Matematika dengan pokok bahasan pengenalan pecahan sederhana berdampak pada rendahnya hasil belajar siswa, yaitu hanya mencapai 50\%. Hasil belajar siswa ini diperoleh dari hasil ulangan harian siswa yang dilakukan pada akhir pokok bahasan. Untuk mengatasi masalah tersebut, maka perlu diadakan upaya inovasi pembelajaran dengan menerapkan pembelajaran yang berpusat pada siswa. Salah satu metode yang diterapkan agar pembelajaran berpusat pada siswa adalah metode inkuiri. Dengan metode inkuiri siswa lebih aktif, karena siswa diberikan kesempatan untuk berpikir dan menemukan sendiri sesuatu melalui pengamatan langsung sehingga siswa akan merasa dirinya yang menemukannya. Sedangkan dalam keterbatasan media guru bisa menggunakan benda konkret yaitu benda-benda berupa biji-bijian, kartu-kartu, alat permainan atau lembar kerja yang dapat dimanipulasi langsung oleh siswa. Dengan adanya solusi ini diharapkan hasil belajar siswa kelas III SD Negeri 6 Tianyar Barat akan mengalami peningkatan.

Bertolak dari uraian di atas, maka penelitian ini mengkaji tentang penerapan Metode Inkuiri Berbantuan Media Benda Konkret untuk meningkatkan Hasil Belajar Matematika pada topik pecahan khususnya bagi siswa kelas III SD Negeri 6 Tianyar Barat Tahun pelajaran 2010/2011.Subjek penelitian tindakan kelas ini adalah siswa kelas III semester 2 SD Negeri 6 Tianyar Barat tahun pelajaran 2010/2011 dengan jumlah siswa yang diteliti adalah 10 orang yang terdiri dari 6 perempuan dan 4 laki-laki.

\section{Metode}

Jenis penelitian inin adalah penelitian tindakan kelas (PTK) yang kegiatan penelitiannya dilaksanakan dari tanggal 16 Januari sampai 20 Februari 2011, di SD Negeri 6 Tianyar Barat Kecamata Kubu, Kabupaten Karangasem. Menurut Arikunto, dkk (2009) mendefinisikan bahwa penelitian tindakan kelas merupakan "suatu pencermatan terhadap kegiatan belajar berupa sebuah tindakan, yang sengaja dimunculkan dan terjadi di sebuah kelas bersama". Sedangkan Supardi, dkk (2009) bahwa penelitian tindakan kelas merupakan "suatu pendekatan untuk meningkatkan pendidikan dengan melakukan perubahan ke arah perbaikan terhadap hasil pendidikan dan pembelajaran".

Berdasarkan definisi di atas, dapat disimpulkan bahwa penelitian tindakan kelas merupakan suatu tindakan yang dimunculkan di kelas untuk memperbaiki praktek pembelajaran guna meningkatkan mutu pembelajaran.Rancangan penelitian tindakan kelas ini dilaksanakan dalam 2 (dua) siklus. Setiap siklus menggunakan model pendekatan yang ditemukan oleh Arikunto, (2009) yang pelaksanaannya terdiri dari 4 tahap yaitu: a. perencanaan, b. tindakan, c. evaluasi, d. refleksi. Siklus ini dapat digambarkan sebagai berikut.

RencanaPenelitian Tindakan KelasSiklus I dan II

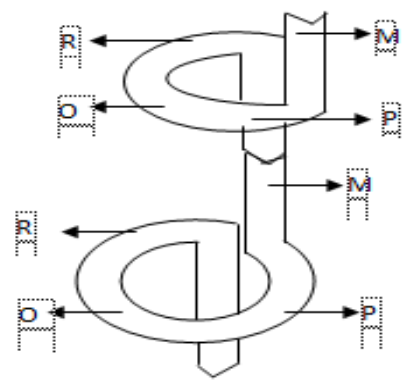

Diagram 01. Model PTK Kemmis dan MC Taggart (Wardani, 2004 )

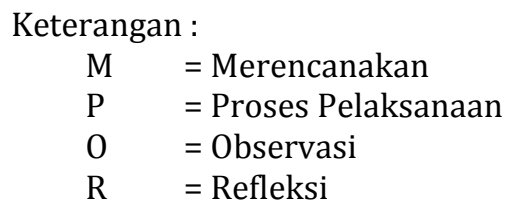


Adapun instrumen pengumpulan data yang digunakan oleh peneliti untuk memperoleh data yang lengkap dan menghasilkan suatu kesimpulan dalam penelitian ini, digunakan metode sebagai berikut :Metode tes yang digunakan adalah metode tes uraian (essay). Tes uraian menurut Agung (1999) merupakan "butir tes (soal) yang mengandung pertanyaan atau tugas yang jawaban dan pengerjaan tugas tersebut harus dilakukan dengan cara mengekspresikan pikiran siswa secara tertulis". Alat pengumpulan data berupa butir-butir soal (tes) untuk mengukur Hasil belajar siswa pada mata pelajaran Matematika dalam topik pecahan setelah diterapkan media benda konkret.

Metode observasi adalah "suatu cara memperoleh data dengan jalan mengadakan pengamatan dan pencatatan secara sistematis tenatng suatu objek tertentu", (Agung, 1999). Observasi yang dilakukan adalah observasi berstruktur dan observasi partisipasi. Obervasi dalam hal ini observer ikut berpatisipasi ke dalam situasi lingkungan tempat penelitian dilakukan. Alat pengumpulan data berupa lembar observasi yang digunakan untuk mengamati secara langsung tingkat aktivitas siswa di dalam kelas pada mata pelajaran Matematika dalam topik pecahan pada saat penerapan media benda konkret

Data mengenai Hasil belajar siswa diperoleh melalui pemberian tes hasil belajar yang dilakukan pada akhir pertemuan di masing-masing siklus. Jumlah soal tes Hasil belajar adalah sebanyak 20. Bobot skor dari masing-masing soal yang diberikan adalah 1.Analisis data dalam penelitian ini adalah menggunakan rumus statistik deskriptif kuantitatif. Yaitu "suatu cara pengolahan data yang dilakukan dengan jalan menyusun secara sistematis dalam bentuk angka-angka atau presentase mengenai suatu objek yang diteliti, sehingga diperoleh kesimpulan umum". (Agung, 1999). Hasil analisis presentase tingkat Hasil belajar siswa yang diperoleh selanjutnya dikonversikan ke dalam Penilaian Acuan Patokan (PAP) skala lima dengan berpedoman pada kriteria seperti tabel berikut ini.

Tabel 1. Kriteria PAP Skala 5 adalah sebagai berikut.

\begin{tabular}{ll}
\hline Presentase & Tingkat Hasil belajar \\
\hline $85 \%-100 \%$ & Sangat Tinggi \\
$70 \%-84 \%$ & Tinggi \\
$55 \%-69 \%$ & Sedang \\
$40 \%-54 \%$ & Rendah \\
$0 \%-39 \%$ & Sangat Rendah \\
\hline
\end{tabular}

(Nurkancana, 1990)

\section{Hasil Dan Pembahasan}

Berdasarkan pelaksanaan proses pembelajaran matematika sub pokok bahasan bilangan pecahan sederhana dengan penerapan metoda inkuiri berbantuan rmedia benda konkrit pada tiap siklus diperoleh hasil sebagai berikut.

\section{Hasil Penelitian Siklus I}

Berdasarkan hasil tindakan siklus I data aktivitas belajar Matematika siswa kelas III SDN 6 Tianyar Barat dapat dilihat dalam tabel 2.

Tabel 2. Data Skor Aktivitas Belajar Matematika siswa kelas III SDN 6 Tianyar Barat tahun Pelajaran 2010/2011

\begin{tabular}{ccc}
\hline No & Kode Siswa & Skor Hasil BelajarSiklus I \\
\hline 1 & 001 & 45 \\
2 & 002 & 60 \\
3 & 003 & 70 \\
4 & 004 & 50 \\
5 & 005 & 63 \\
6 & 006 & 52 \\
7 & 007 & 64 \\
8 & 008 & 54 \\
9 & 009 & 40 \\
10 & 010 & 48
\end{tabular}




\begin{tabular}{cc} 
Jumlah & 546 \\
\hline Skor Rata-rata & 54,6 \\
\hline
\end{tabular}

berikut:

Berdasarkan data hasil belajar itu pula dihitung ketuntasan belajanya dengan rumus sebagai

$$
\begin{aligned}
\mathrm{KB} & =\text { banyaknya siswa yang memperoleh nilai lebih dari }>55 \times 100 \\
K B & =\frac{4}{10} \times 100 \% \\
K B & =40 \%
\end{aligned}
$$

Jadi rata-rata hasil bealajar adalah adalah 54,6 , daya serap 54,6 dan ketuntasan belajar siswa adalah $40 \%$. Dalam pelaksanaan tes hasil belajar pada siklus 1 siswa yang mengikuti tes adalah sebanyak 10 orang siswa. Tes yang diberikan pada siswa merupakan tes pilihan ganda yang harus dikerjakan secara individu bukan kelompok. Dalam mengerjakan tes pilihan ganda, siswa tidak diperbolehkan untuk mencontek jawaban temann. Untuk menghindari adanya siswa yang mencontek jawaban temannya, maka siswa di minta duduk berjauhan dan siswa di awasi secara ketat dalam mengerjakan soal. Hal ini di lakukan untuk mengetahui sejauh mana kemampuan siswa dalam memahami materi yang telah disampaikan

Untuk mengetahui data tentang data siswa, digunakan metode tes yaitu berupa pilihan ganda yang dilaksanakan pada akhir siklus. Jumlah soal pada tes pilihan ganda yaitu 20 butir soal dengan bobot soal 1. Jadi skor maksimal ideal untuk soal yang disajikan adalah 20.Berdasarkan hasil pengumpulan data dengan menggunakan metode tes tersebut maka dapat disajikan data tentang hasil belajar kognitif siswa dalam sub pokok bahasan pecahan sederhana pada siklus I.

Berdasarkan pada tabel 2 maka dapat diketahui bahwa jumlah siswa yang memperoleh nilai $<55$ adalah sebanyak 6 orang dan jumlah siswa yang memperoleh nilai $>55$ adalah 6 orang. Berdasarkan analisis test belajar didapatakan bahwa rata-rata hasil belajar 54,6 sehingga hasil belajar siswa rendah karena belum mencapai ketuntasan belajar minimal yaitu 55siklus 1, diketahui hasil belajar siswa belum memenuhi kriteria ketuntasan yang telah ditetapkan. Untuk itu proses pembelajaran dilanjutkan pada siklus II. Pada siklus 1 terungkap beberapa kendala yang dialami dalam melaksanakan proses pembelajaran dengan menerapkan metode inkuiri berbantuan media benda konkrit.

Kendala-kendala yang dialami selama penerapan metode inkuiri berbantuan media benda konkrit dalam pelaksanaan pembelajaran siklus 1 adalah sebagai berikut, pertama Siswa kelihatan bingung dalam melakukan pengamatan sehingga siswa sering mengganggu temannya dan bercanda, kedua Siswa tidak terbiasa melakukan kerja ilmiah sehingga belum memahami apa yang diharapkan melalui kegiatan menemukan sendiri. Ketiga Siswa kurang termotivasi untuk menjawab pertanyaan dan mengungkap pendapat dalam kelompok. Keempat Siswa kurang aktif berpartisivasi dalam mengikuti proses pembelajaran. Kelima Suasana pembelajaran yang kurang kondusip karena siswa merasa bosan mengikuti pelajaran dikelas.Kendala-kendala yang dihadapi selama siklus1 ini, dipergunakan sebagai acuan untuk melaksanakan perbaikan pada pembelajaran siklus 2 .

\section{Hasil Penelitian Siklus II}

Dalam perencanaan siklus II kegiatan yang dilakukan yaitu membuat silabus, menyiapkan rencana pelaksanaan pembelajaran berbasis inkuiri yang merupakan perbaikan dari siklus 1 , menyiapkan alat berupa cutter yang digunakan dalam mengamati buah apel, dan menyediakan tes hasil belajar untuk mengukur kemampuan siswa berupa tes dan lembar observasi. Data hasil belajar kognitif sisswa pada siklus Idikumpulkan melalui metode tes berupa tes pilihan ganda yang dilaksanakan pada akhir siklus. Jumlah soal pada tes pilihan ganda yaitu 20 butir dengan bobot setiap soal satu, jadi skor maksimal ideal untuk soal yang disajikan adalah 20. Tes yang digunakan untuk menilai hasil belajar siswa pada akhir siklus dan lembar observasi digunakan untuk belajar afektif dan psikomotor siswa pada setiap pertemuan. Berikut data hasil belajar yang diperoleh pada siklus II.

Tabel 3. Data hasil Belajar Siklus II

\begin{tabular}{ccc}
\hline No & Kode Siswa & Skor Hasil BelajarSiklus II \\
\hline 1 & 001 & 70 \\
2 & 002 & 80 \\
3 & 003 & 85 \\
4 & 004 & 80
\end{tabular}




\begin{tabular}{ccc}
\hline No & Kode Siswa & Skor Hasil BelajarSiklus II \\
\hline 5 & 005 & 50 \\
6 & 006 & 80 \\
7 & 007 & 80 \\
8 & 008 & 80 \\
9 & 009 & 53 \\
10 & 010 & 80 \\
\hline & Jumlah & 738 \\
\hline & Skor Rata-rata & 73,8 \\
\hline
\end{tabular}

Berdasarkan data pada tabel 3 maka dapat diketahui bahwa siswa yang memperoleh nilai $<55$ adalah sebanyak 2 orang dan jumlah siswa yang memperoleh nilai >_55 adalah sebanyak 8 orang.Hasil tingkat ketuntasan klasikal yang telah dicapai pad siklus II yaitu $80 \%$. Apabila dibandinngkan dengan kriteria PAP skala lima ternyata berda pada kategori $80 \%-100 \%$. Hal ini bearti bahwa hasil belajar kognitif sioswa dalam sub pokok pecahan sederhana dan lammbangnya berada pada kategori baik.

Untuk data rekapitulasi hasil belajar kognitif siswa pada sub pokok bahasan perbandingan pecahan dan memecahkan masalah yang melibatkan pecahan yang telah dicapai pada masing-masing siklus pada dilihat pada tabel 4 .

Tabel 4. Rekapitulasi hasil belajar kognitif yang dicapai siswa

\begin{tabular}{cccc}
\hline \multirow{2}{*}{ No } & \multirow{2}{*}{ Keterangan } & \multicolumn{2}{c}{ Hasil belajar kognitif } \\
\cline { 3 - 4 } & & Siklus I & Siklus II \\
\hline 1. & Nilai $<55$ & 6 orang & 2 orang \\
2. & Nilai $>55$ & 4 orang & 8 orang \\
3. & Ketuntasan Klasikal (KK) & $40 \%$ & $80 \%$ \\
4. & Kategori & Cukup baik & Sangat Baik \\
\hline
\end{tabular}

Dari Tabel 4 menujukan bahwa pada siklus 1 ketentuan klasikal yang dicapai sebesar $40 \%$ dengan kategori cukup dan pada siklus II ketuntasan klasikal yang dicapai sebesar $80 \%$ dengan kategori sangat baik. Hal ini menunjukkan terjadi peningkatan hasil belajar kognitif siswa dari cukup pada siklus I menjadi kategori sangat baik pada siklus II.Berdasarkan rekapitulasi hasil belajar kognitif siswa yang disajikan pada Tabel 4 maka data tersebut dapat disajikan dalam bentuk grafik batang sebagai berikut.

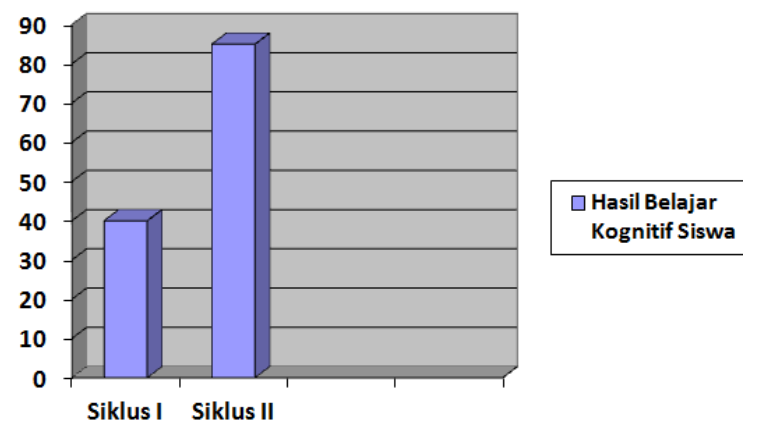

Gambar 1. Grafik Batang hasil belajar kognitif siswa

Berdasarkan hasil analisis siklus II , maka dapat diketahui telah terjadi peningkatan hasil belajar siswa dibandingkan dengan siklus I. Peningkatan yang tercapai pada siklus II terjadi karena telah dilakukan perbaikan proses pembelajaran yang membuat siswa lebih termotivasi, disiplin dan aktif, dalam menguikuti proses pembelajaran. Pada siklus II, secara klasikal hasil belajar sisiwa telah memenuhi kriteria ketuntasan klasikal sehingga pembelajaran tidak dilanjutkan pada siklus selanjutnya.

Beberapa hal yang dapat dijadikan refleksi terkait dengan proses penilaian dalam pembelajaran pada siklus II yaitu : 1) Keberanian siswa dalam mengemukakan pendapat dan menjawab pertanyaan sudah meningkat walaupun masih ada beberapa siswa yang tidak dapat mengemukakan pendapatnya. 2) Kerjasama siswa meningkat. Hal ini terlihat pada saat melakukan percobaan dan diskusi kelompok. Anggota kelompok terlihat aktif baik dalam melakukan percobaan maupun dalam melakukan diskusi. 3) 
Kedisiplinan siswa dalam proses pembelajaran sudah meningkat. Dalam proses pembelajaran siswa sudah bisa tertib, walaupun ada beberapa siswa yang masih mengganggu temannya.

Berdasarkan hasil ulangan pada pokok bahasan mengenal pecahan sederhana dan penggunaan pecahan sebelum diterapkan metode inkuiri bermedia benda konkrit ternyata hasil belajar siswa belum memenuhi tingkat ketuntasan klasikal. Hal ini dapat diketahui dari nilai ketuntasan klasikal prasiklus yang masih cenderung rendah yaitu 50\%. Padahal nilai KKM untuk mata pelajaran Matematika yang harus dipenuhi oleh setiap siswa adalah 60. Nilai siswa yang belum memenuhi KKM disebabkan oleh cara mengajar guru yang masih menerapkan metode ceramah. Menurut Dimyanti \& Mudjiono (dalam Wirawan, 1999) guru hendaknya tidak lagi mengajar sekedar sebagai kegiatan menyampaikan pengetahuan, keterampilan dan sikap pada siswa. Guru hendaknya mengajar untuk membelajarkan siswa dalam konteks belajar bagaimana belajar mencari, menemukan, dan meresapkan pengetahuan, keterampilan, dan sikap. Untuk itu, guru hendaknya dapat menerapkan metode pembelajaran yang dapat mengaktifkan siswa. Selain metode pembelajaran, penggunaan media dalam mengajar juga harus diperhatikan. Tetapi realitanya guru kelas III SD Negeri Tianyar Barat pada saat mengajar Matematika tidak menggunakan media dalam mengajar subpokok bahasan pengenalan pecahan. Para guru dapat memanfaatkan media benda konkrit berupa buah apel dan jeruk dalam mengajar subpokok bahasan pengenalan pecahan . Dengan menggunakan media benda konkrit dapat menarik minat belajar siswa. Hal ini diungkapkan oleh Sumantri \& Johar (1999) bahawa media benda konkrit merupakan benda yang sebenarnya dan cenderung dapat menarik minat belajar siswa. Bertolak dari kondisi awal tersebut dilakukan penelitian tindakan kelas untuk mengoptimalkan hasil belajar siswa melalui penerapan metode inkuiri berbantuan media benda konkrit dalam subpokok bahasan pengenalan pecahan.

Hasil tes kognitif siswa pada siklus I dengan metode inkuiri berbantuan rmedia benda konkrit rata-rata skor siswa yang tuntas atau mendapat nilai $>60$ adalah sebanyak 6 orang siswa dengan tingkat ketuntasan belajar sebesar $60 \%$. Hal ini berarti bahwa 4 siswa memperoleh nilai dibawah 60 . Dari tingkat ketuntasan klasikal 60\% menunjukkan pengetahuan siswa tentang materi pengenalan pecahan masih minim atau belum optimal. Pada siklus I untuk hasil belajar kognitif siswa apabila dibandingkandengan kriteria PAP skala lima berada pada dikatagorikan cukup.

Peningkatan hasil belajar yang dianggap masih belum optimal pada siklus I ini terjadi karena adanya kendala-kendala yang dialami dalam melaksanakan proses pembelajaran dengan menerapkan metode inkuiri berbantuan media benda asli. Adapun kendala-kendala yang dialami selama menerapkan metode inkuiri berbantuan media benda asli adalah: 1) Siswa masih kelihatan bingung dalam melakukan pengamatan, sehingga siswa sering mengganggu temannya dan bercanda. 2) Siswa tidak terbiasa untuk melakukan kerja ilmiah sehingga belum memahami apa yang diharapkan melalui kegiatan menemukan sendiri. 3) Dari kendala-kendala yang dialami pada siklus I maka pada siklus II dilakukan perbaikan proses pembelajaran agar pada siklus II terjadi peningkatan yang optimal.

Untuk hasil observasi afektif dan psikomotor siswa pada siklus I belum memenuhi kriteria yang diharapkan. Pada siklus I, hasil belajar afektif siswa yaitu sebesar 60\% dengan kategori cukup sedangkan untuk hasil belajar psikomotor siswa yaitu 50\% dengan kategori kurang. Hasil yang belum memenuhi harapan tersebut karena sebagian besar siswa tidak mau terlibat aktif berpartisipasi dalam mengikuti proses pembelajaran, sebagian siswa yang mengganggu temannya saat kerja kelompok, siswa kurang termotivasi untuk menjawab pertanyaan dan mengungkapkan pendapat dalam kelompok, suasana pembelajaran yang kurang kondusif karena siswa merasa bosan mengikuti pembelajaran di kelas.

Pada siklus II hasil tes kognitif siswa ternyata terjadi peningkatan yang berada pada kategori tinggi dengan sangat baik ketuntasan klasikal sebesar $80 \%$. Hal ini berarti bahwa 8 orang siswa memperoleh nilai $>55$ dan hanya 2 orang siswa yang memperoleh nilai $<55$. Dari data tersebut dapat disimpulkan bahwa penerapan metode inkuiri berbantuan media benda konkrit dapat meningkatkan hasil belajar kognitif siswa dalam pokok bahasan pengenalan pecahan dan penggunaan pecahan.

Peningkatan yang terjadi pada siklus II karena kendala-kendala yang dialami dalam melaksanakan proses pembelajaran dengan menerapkan metode inkuiri berbantuan media benda konkrit telah ditanggulangi dan diperbaiki. Perbaikan yang dilakukan dalam proses pembelajaran yaitu : 1) Berkeliling dari satu kelompok ke kelompok lain untuk memberi arahan kepada siswa yang kelihatan agak bingung. 2) Memberikan lembar kerja siswa sebelum dilakukan kegiatan belajar mengajar agar dapat dipelajari sebelumnya. 3) Memberi arahan kepada siswa tentang kerja ilmiah sehingga siswa dapat memahami apa yang diharapkan melalui kegiatan menemukan sendiri.

Untuk hasil belajar afektif dan psikomotor siswa pada siklus II dapat dikategorikan sangat aktif. Hal; ini terjadi karena telah dilakukan perbaikan proses pembelajaran. Perbaikan proses pembelajaran pada siklus II yaitu:1) Memotivasi siswa untuk menjawab pertanyaan dan mengungkapkan pendapat dalam kelompok. 2) Menegur siswa yang bercanda dan mengganggu temannya. 3) Tidak selalu melakukan 
percobaan di dalam kelas, tetapi diberikan suasana baru dengan mengajak siswa melakukan percobaan diluar kelas.

Pencapaian hasil belajar afektif dan psikomotor siswa pada siklus II telah memenuhi kriteria yang telah ditetapkan jika dibandingkan dengan hasil belajar pada siklus I dan sebelum tindakan. Peningkatan hasil belajar pada siklus II tersebut terjadi karena pada siklus II telah diadakan perbaikan pembelajaran dan kekurangan-kekurangan yang ditemukan pada siklus I telah diatasi

\section{Simpulan Dan Saran}

Berdasarkan hasil analisis data dan pembahasan yang telah disajikan, maka dapat ditarik kesimpulan bahwa penerapan media benda konkret dalam proses pembelajaran dapat meningkatkan Hasil belajar Matematika pada topik pecahan siswa kelas III SD Negeri 6 Tianyar Barat Semester II dengan perolehan angka rata-rata Hasil kelas pada siklus I sebesar 65\% berada pada kategori sedang. Sedangkan pada siklus II sebesar $83 \%$ berada pada kategori tinggi. Dengan demikian, dari siklus I ke siklus II mengalami peningkatan sebanyak 18\%. Penerapan media benda konkret ternyata sangat efektif dalam meningkatkan Hasil belajar Matematika khususnya pada pokok bahasan pengenalan pecahan sederhana siswa kelas III SD Negeri 6 Tianyar Barat Kecamatan Kubu Kabupaten Karangasem tahun pelajaran 2010/2011.

Bertitik tolak dari simpulan di atas, maka dapat dijadikan saran-saran sebagai berikut. 1) Kepada seluruh siswa kelas III SD Negeri 6 Tianyar Barat agar dalam proses pembelajaran yang menggunakan media benda konkret selalu mengikuti dan memperhatikan dengan sungguh-sungguh sehingga dapat menguasai materi pelajaran dengan baik. 2) Kepada guru-guru pengajar bidang studi Matematika di Sekolah Dasar agar dalam mengelola proses pembelajaran perlu mencoba menerapkan media benda konkret sehingga dapat keterampilan proses dan Hasil belajar Matematika khususnya pada pokok bahasan pengenalan pecahan sederhana pada siswa. 3) Kepada Kepala Sekolah disarankan agar dapat menciptakan kondisi yang mampu mendorong para guru untuk mencoba menerapkan media benda konkret dalam pembelajaran Matematika khususnya dan bidang studi lain pada umumnya.4) Kepada peneliti lain yang berminat untuk mengadakan penelitian lebih lanjut mengenai penerapan media benda konkret pada bidang ilmu Matematika maupun bidang ilmu lainnya yang sesuai, agar penelitian ini dapat dijadikan acuan atau referensi demi ketuntasan penelitian selanjutnya dan memperhatikan kendalakendala yang peneliti alami sebagai bahan pertimbangan untuk perbaikan dan menyempurnakan pelaksanaan penelitian.

\section{Daftar Pustaka}

Agung, A.A. G. 1999. Metodologi Penelitian Pendidikan. Singaraja. STKIP Singaraja

Ali. 1992. Strategi Belajar Mengajar Bahasa Indonesia

Arikunto, Suharsimi, dkk. 2009. Penelitian Tindakan Kelas. Jakarta : Bumi Aksara

Aryati, Luh. 2003. Penggunaan Media Benda Konkret untuk Meningkatkan Hasil Belajar dalam Pembelajaran Matematika pada Siswa Kelas I Semester I di SD No. 3 Sidatapa Kecamatan Banjar Singaraja. Skripsi (Tidak Diterbitkan). Institut Keguruan dan Ilmu Pendidikan Negeri Singaraja. Bandung: Pustaka Setia

Depdikbud. 2005. Pengelolaan Bagi Guru Mata Pelajaran .

Imbrahim dan Syiadil. 1993. Perencanaan Pengajaran. Jakarta: Depdikbud Dirjen Dikti Jakarta : Direktorat Pendidikan Menengah Umum

Nurkancana, Wayan dan Sunartana. 1990. Evaluasi Hasil Belajar. Surabaya : Usaha Nasional

Purwanto, Metedeologi Penelitian Pendidikan. Surabaya: SIC

Rusyan, A. Tabrani. 1993. Proses Belajar Mengajar yang Efektif Tingkat Pendidikan Dasar. Bandung : Bina Bhudaya

Setiadi. 2003. Implementasi pembelajaran dengan pendekatan bernabtuan LKS kontekstual sebagai upaya untuk meningkatkan konsep diri dan kompetensi dasar matematika kelas siswa kelas VIIIA SMP N 4 Singaraja tahun ajaran 2005/2006.Undiksha Singaraja.

Sudarma, I Komang dan Parmiti, Desak Putu. 2007. Media Pembelajaran. Singaraja. Undiksha 
Sudjana, Nana. 2006. Penilaian Proses Belajar Mengajar. Bandung: Remaja Rosdakarya

Suherman, dkk. 2003. Metedeologi Penelitian Sosial dan Pendidikan .Jakarta:Bumi Aksara

Sumantri, dkk.1999. Strategi Belajar Mengajar. Jakarta: Depdikbud Dirjen Dikti

Supardi, dkk. 2009. Pengertian Tindakan Kelas. Jakarta : Bumi Aksara

Suryasubroto. B. 2006. Proses Belajar Mengajar di Sekolah. Jakarta: Rineka Cipta.

Suwatra, dkk. 2007. Model Pembelajaran Tife Student Teams achivement devision (STAD) sebagai upaya meningkatkan hasil belajar siswa dalam pembelajaran matematika pada siswa kelas IV SD Negeri 1 Tulamben Kecamatan Kubu.Tahun pelajaran 2008/2009.Skripsi (tidak diterbitkan). Jurusan Pendidikan guru sekolah dasar, undiksha singaraja

Wardani. 2004. Penerapan Beberapa Jenis Media Belajar Dalam Pelajaran Matematika Kelas III di Sekolah Dasar No 2 Bulian,Kecamatan Kubutambahan Kabupaten Buleleng.tahun ajaran 1998/1999. Sekripsi (tidak diterbitkan). Jurusan teknologi pendidikan, STKIP Singaraja.

Zainudin. 1988. Media Intruksional Edukatif.Jakarta: Rineka Cipta 